\title{
FIRST RECORD OF STOREYINAE, A VERY RARE SUBFAMILY OF PTEROMALIDAE (HYMENOPTERA: CHALCIDOIDEA) FROM INDIA WITH THE DESCRIPTION OF A NEW SPECIES
}

\author{
P.M. Sureshan
}

Zoological Survey of India, Western Ghats Field Research Station, Annie Hall Road, Calicut, Kerala 673002, India

\begin{abstract}
Storeyinae, a very rare subfamily of Pteromalidae, is reported for the first time from India with a new species Storeya minuta sp.nov. from Eravikulam National Park, Kerala.
\end{abstract}

\section{Key words}

Pteromalidae, Storeyinae, Storeya minuta, new species.

$$
\begin{aligned}
& \text { MV = Marginal vein } \\
& \text { POL }=\text { Post-ocellar distance }
\end{aligned}
$$

\section{Abbreviations}

$$
\begin{array}{r}
\text { OOL }=\text { Ocell-ocular distance } \\
\text { STV }=\text { Stigmal vein }
\end{array}
$$

\section{Introduction}

Boucek (1988) erected the subfamily Storeyinae in Pteromalidae (Chalcidoidea) solely for the rare genus Storeya Boucek with the type species Storeya paradoxa Boucek from Queensland, Australia. He also mentioned the occurrence of Storeya in Nepal based on an undescribed species. During the faunal explorations of Eravikulam National Park, a conservation area located in the high ranges of Kerala, I could collect one male specimen of Storeya from Sambamalai, at about 2,200 metres. On detailed examination, it was found that the specimen belongs to a new species of Storeya Boucek, which is described here. This forms the first record of the subfamily from India, one more addition of a species under the genus Storeya from the world and the first record of a male under the genus. The type material is deposited in the faunal holdings of Zoological Survey of India, Calicut.

\section{Storeya minuta sp.nov.}

(Figs. $1 \& 2$ )

\section{Material examined}

Holotype: 1 male; India: Kerala, Eravikulam National Park, Sambamalai, 28.ii.1993. Coll.P.M. Sureshan (ZSI, Calicut).

Etymology: Species name pertains to the minute size of the specimen.

Received 3 July 1999;

Accepted 1 September 1999

\section{Diagnostic features:}

Male: Length $1 \mathrm{~mm}$. Body dark brown, metallic; antennal scape honey yellow with a subapical whitish ring; tip of scape to club brown; club whitish; coxae concolorous with thorax except tips of fore and hind coxae whitish, remainder of legs pale brown, with tarsi pale testaceous; petiole with distal half white; wings subhyaline with an infumation at base, a cross band at parastigma and a broad infumation in distal third, but not reaching apical margin; veins pale brown.

Head: (Figs. $1 \&$ 2) Shiny, in front view width $1.2 \mathrm{x}$ height; anterior margin of clypeus slightly emarginate; eyes seperated by a distance little greater than their individual length; eye length 1.5 $\mathrm{x}$ width (in profile); malar space length $0.7 \mathrm{x}$ eye length; POL very slightly longer than OOL; temple length 0.2 x eye length; genae at mouth margin deeply impressed, corner margin carinate. Antennae (Fig.1) with scape $1.3 \mathrm{x}$ as long as eye; pedicel length equal to length of first three funicle segments combined; first funicle segment shortest, only $0.2 \mathrm{x}$ as long as pedicel and distinctly shorter than second; club little longer than two preceeding segments combined.

Thorax: (Fig. 1) Shiny, narrowed at both ends, length $1.8 \mathrm{x}$ width; pronotal collar not indicated. Mesoscutum with notauli slightly indicated anteriorly, strongly converging. Scutellum transverse, with sub-lateral grooves curving outwards. Propodeum convex, without lateral hairs; spiracles very small; posterior border slightly constricted throughout with several carinulae; adpetiolar border 


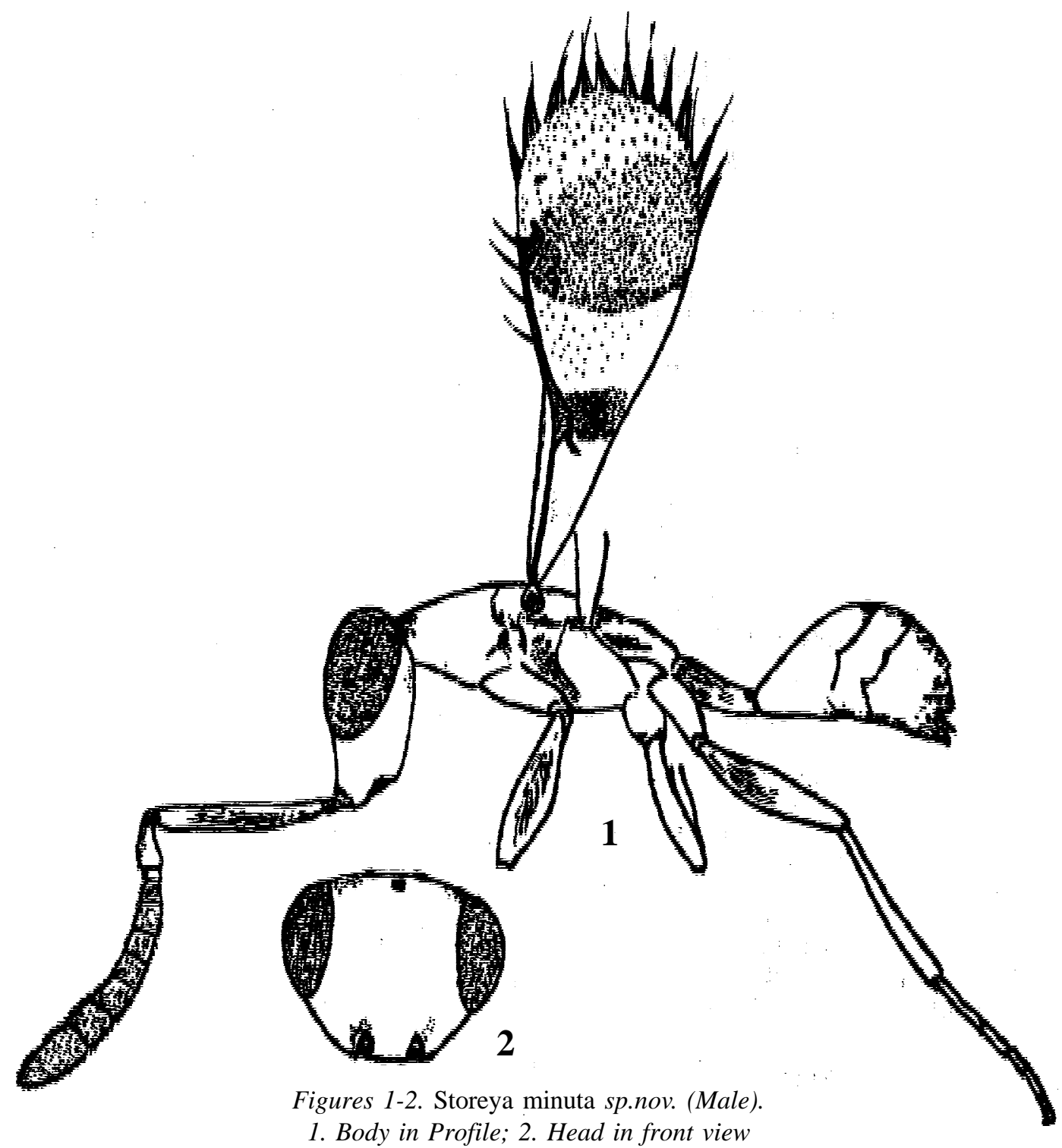

deeply emarginate. Metapleuron not reaching hind wing base; mesepimeron smooth; mesepisternum depressed and finely reticulate. Prepectus broad, triangular, smooth. Legs slender. Fore Wing (Fig. 1) narrow, length $2.4 \mathrm{x}$ width, with a tuft of few scales at parastigma. Relative lengths: Costal cell 13, MV 8, STV 2.

Gaster: (Fig.1) collapsed, petiole length $2.5 \mathrm{x}$ its width; length of gaster plus petiole $0.8 \mathrm{x}$ that of head and thorax combined.

Remarks: This species closely resembles $S$. paradoxa in general morphology but differs in having antenna with first funicular segment very short, broader fore wing, length $2.4 \mathrm{x}$ width with a tuft of narrower scales at parastigma and in general colouration of the body including gaster dark brown and body without violet hue. (In $S$. paradoxa first funicular segment is not distinctly shorter than others; forewing more narrow, length $2.8 \mathrm{x}$ width with a tuft of broad scales at parastigma. In addition, its body is pale honey yellow, with faint violet hue in places and gaster dark green to cupreous).

\section{Acknowledgements}

I am grateful to the Director, Zoological Survey of India, Calcutta, and the Officer-in-charge, Zoological Survey of India, Western Ghat Field Research Station, Calicut, for providing facilities and encouragement. I am also grateful to Dr.T.C. Narendran, Professor of Zoology, University of Calicut, for guidance and valuable suggestions in finalising the paper.

\section{References}

Boucek, Z. (1988). Australasian Chalcidoidea (Hymenoptera). C.A.B. International, Wallingford, U.K. pp. 284-285. 